\title{
Sensory analysis of curly kale produced under conventional and hydroponic systems
}

\author{
Análise sensorial de couve de folha crespa produzida em \\ sistemas convencional e hidropônico
}

\author{
Lorena Caroline da Silva ${ }^{1}$, Daniella Martins Pimenta ${ }^{1}$, Victor Augusto Forti ${ }^{1}$, \\ Fernando Cesar Sala ${ }^{2}$, Simone Daniela Sartorio de Medeiros ${ }^{3}$ (D), \\ Marta Regina Verruma-Bernardi* (1)
}

\author{
1Universidade Federal de São Carlos (UFSCar), Centro de Ciências Agrárias, Departamento de Tecnologia \\ Agroindustrial e Socioeconomia Rural, Araras, SP, Brasil \\ 2Universidade Federal de São Carlos (UFSCar), Centro de Ciências Agrárias, Departamento de Biotecnologia e \\ Produção Vegetal e Animal, Araras, SP, Brasil \\ ${ }^{3}$ Universidade Federal de Santa Catarina (UFSC), Departamento de Informática e Estatística, do Centro \\ Tecnológico, Florianópolis, SC, Brasil
}

*Corresponding Author: Marta Regina Verruma-Bernardi, Universidade Federal de São Carlos (UFSCar), Centro de Ciências Agrárias, Departamento de Tecnologia Agroindustrial e Socioeconomia Rural, Rodovia Anhanguera, SP-330, km 174, CEP: 13604-900, Araras/SP - Brasil. 19 35432614. verruma@ufscar.br

Cite as: Silva, L. C., Pimenta, D. M., Forti, V. A., Sala, F. C., Medeiros, S. D. S., \& Verruma-Bernardi, M. R. (2021)

Sensory analysis of curly kale produced under conventional and hydroponic systems. Brazilian Journal of Food

Technology, 24, e2020192. https://doi.org/10.1590/1981-6723.19220

\begin{abstract}
The consumption and cultivation of curly kale in Brazil is recent and information on production systems and their acceptance by the consumer are scarce. The aim of this work was to evaluate the sensory characteristics of curly kales cultivated using the conventional and hydroponic systems, considering the treatments: cultivation under the conventional system, without fertilization (A), conventional system with organic fertilizers $(C, E)$ and hydroponic system (F). The harvests were performed at 60,90 and 120 days after planting for the plants cultivated using the conventional system and at 30 days for the hydroponic system. The total chlorophyll index content and the sensory analyses of ranking of difference and acceptance were analyzed. The lowest chlorophyll index in the curly kales was verified for the one cultivated under the hydroponic system. In the ranking test, the darkest green color was obtained for the curly kale produced using the conventional system and for the attributes aroma, sweet and bitter taste and crunchiness, there was no significant difference.
\end{abstract}

Keywords: Brassica oleraceae var acephala; Organic fertilizers; Ranking test; Acceptance test; Color; Chlorophyll index.

\section{Resumo}

O consumo e o cultivo da couve de folha crespa no Brasil são recentes e mostram-se escassas as informações sobre sistemas de produção e sua aceitação pelo consumidor. $\mathrm{O}$ objetivo do trabalho foi avaliar as características sensoriais de couves de folhas crespas cultivadas em sistemas convencional e hidropônico, considerando os tratamentos: cultivo sistema convencional, sem adubação (A), sistema convencional com fertilizantes orgânicos ( $C$, E) e sistema hidropônico (F). As colheitas foram realizadas aos 60, 90 e 120 dias após plantio para as plantas cultivadas em sistema convencional e, aos 30 dias, para o sistema hidropônico. Foi analisado o teor do índice de clorofila total e realizada a análise sensorial de 
ordenação de diferença e aceitação. O índice de clorofila nas couves de folhas crespas no sistema convencional foi menor em relação ao da couve cultivada em sistema hidropônico. Para teste de ordenação, a cor verde foi mais escura na couve crespa produzida em sistema convencional e, para os demais atributos (aroma, gostos doce e amargo, e crocância), não houve diferença significativa.

Palavras-chave: Brassica oleraceae var acephala; Fertilizantes orgânicos; Análise de ordenação; Análise de aceitação; Cor; Índice de clorofila.

\section{Introduction}

The market of vegetables presents several sectors, one of which is non-traditional vegetables, comprising differentiated products, many times not related to unknown vegetable species, but to the variation in size or color compared to conventional vegetables. This segment has been prominent because of the growing interest of consumers in news in the food area for in natura consumption (Vilela \& Macedo, 2000). According to ABCSEM (Associação Brasileira do Comércio de Sementes e Mudas, 2016), studies on habits of leafy vegetable consumption have demonstrated that crunchiness, reduced size, pleasant taste, varied leaf colors and shapes and greater durability are important in the decision of purchase. Among these vegetables is curly kale.

Curly kale, also known as kale, is characterized by leaves along the stem, and it has gained popularity because of its nutritional value, highlighting the protein contents and low calory. In comparison with collardgreen, it has corrugated leaves, usually of dark-green coloration (Olsen et al., 2009).

According to the ANDA - Brazilian National Fertilizer Association (Associação Nacional para Difusão de Adubos, 2016), Brazil is the fourth highest consumer of fertilizers in the world, importing $75 \%$ of these nutrients, most of which deriving from non-renewable sources. As alternative to mineral fertilization, the organic fertilization emerged as a potential for the enhancement of the soil attributes, favoring fertility, benefiting soil biodiversity and vegetable productivity (Finatto et al., 2013). Furthermore, the use of organic fertilizers can promote the rise in water retention capacity of the substrate, higher aggregation of soil particles, and they serve as an important source of nutrients, such as calcium, magnesium, nitrogen and phosphorus (Oliveira et al., 2014).

The determination of vegetable quality consists in the evaluation of the external (size, shape, appearance, color, texture, uniformity, firmness) and internal characteristics, such as aroma, flavor, nutritional value, acidity and the content of total soluble solids (Aular \& Natale, 2013), and it is related to several factors, among which the level of nutrient supply and production systems. Bernardi et al. (2005) reported that the appearance of the vegetables is of major importance since the consumer only acquires the most attractive product.

Kale is usually cultivated in soil; nevertheless, studies have demonstrated that hydroponics is an alternative, with the advantage of anticipating the harvest, which can occur in up to 30 days after seedling transplant (Noboa et al., 2019), whereas for the conventional system, the harvest begins two to three months after culture installation. Additionally, hydroponics is the technique of leafy vegetable cultivation that most grows in Brazil (Lima et al., 2018).

The aim of this work was to compare the sensory characteristics of curly kale cultivated using the conventional system with organic fertilization and the hydroponic system.

\section{Material and methods}

\subsection{Material}

Curly kale, Brassica oleracea var. acephala, Darkibor hybrid, was employed. The treatments were: cultivation using the conventional system, without fertilization (A), conventional system with organic fertilizers $(\mathrm{C}, \mathrm{E})$ and hydroponic system $(\mathrm{F})$. 
The experiment was performed in the Center for Agrarian Sciences (CCA), of the Federal University of

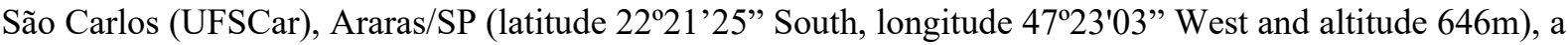
region characterized by dry winter (April to June 2019), a period in which the experiment occurred.

The soil in the area for conventional cultivation was of the Red Latosol type with the following chemical characteristics: $\mathrm{pH}\left(\mathrm{CaCl}_{2}\right)=5.7$; organic matter $=33 \mathrm{~g} \mathrm{dm}^{-3} ; p=7 \mathrm{mg} \mathrm{dm}{ }^{3} ; \mathrm{K}=6.9 \mathrm{mmol} \mathrm{dm}$; $\mathrm{Ca}^{2+}=68 \mathrm{mmol} \mathrm{dm}^{-3} ; \mathrm{Mg}=15 \mathrm{mmol} \mathrm{dm}{ }^{-3} ; \mathrm{Al}=0.5 \mathrm{mmol} \mathrm{dm} ; \mathrm{H}+\mathrm{Al}=21 \mathrm{mmol} \mathrm{dm} \mathrm{dm}^{-3}$; $\mathrm{CTC}=110.9 \mathrm{mmol} \mathrm{dm}^{-3} ; \mathrm{Fe}=43 \mathrm{mg} \mathrm{dm}{ }^{-3} ; \mathrm{Mn}=23.9 \mathrm{mmol} \mathrm{dm}^{-3} ; \mathrm{Zn}=4.6 \mathrm{mmol} \mathrm{dm}^{-3}$ and $\mathrm{Cu}=$ $3.9 \mathrm{mmol} \mathrm{dm}^{-3}$. The composition of the organic fertilizer (C) was chicken manure, bone meal, industrial waste from slaughterhouse and foods, and other industrial wastes, and that of fertilizer (E) was sugarcane filter cake. The quality of both organic fertilizers was in accordance with Brasil (2020). The amounts of the fertilizers, both for planting and cover, were defined according to Trani et al. (2015).

The hydroponic system was of the NFT (nutrient film technique) type, with trapezoidal polypropylene (TP50) profiles, installed under 35\% red screen, benches with a 9\% slope for the flow of the nutrient solution, with spacing of $25 \times 25 \mathrm{~cm}$ between plants and profiles. The hydroponic solution used was the recommended by Furlani et al. (1999).

Kale seedlings were produced in 128-cell trays with substrate and at 30 days after germination they were transplanted to the experimental plots in the conventional and hydroponic systems.

At 60, 90 and 120 days after planting, the kales cultivated using the conventional system with organic fertilizers, and at 30 days for the kales cultivated under the hydroponic system, were harvested, and evaluated regarding their total chlorophyll index and sensory analysis. The leaves used for the sensory analysis and total chlorophyll index were collected from the medium part of the plant. The total chlorophyll index was analyzed using SPAD.

\subsection{Sensory analysis}

\subsubsection{Test conditions}

The study was approved by the Ethics Committee on Human Beings, CAAE n $n^{0}: 95217118.0 .0000 .5504$. The sensory tests were performed at the Laboratory of Sensory Analysis, in individual cabins with white light, and each taster received one leaf from each kale at room temperature, on white plastic dishes and coded with three digits.

In the first test, the ranking test of difference (International Organization for Standardization, 2006) was employed, with adaptations, since the attributes were evaluated in a single test, in order to use the same sample. The kales were presented simultaneously, and the taster was requested to rank in ascending order the attributes: green color, characteristic aroma, sweet taste, bitter taste and crunchiness. The order of presentation was randomized for each taster. The attributes evaluated were based on the study of Noboa et al. (2019) in curly kales.

In the second step, the tasters were characterized regarding age, sex, occupation, and then they were asked about the frequency of kale consumption ( 1 or 2 times per month; 1 or 2 times per week; 3 or more times per week; never or rarely) and how they consume kale (braised, salad, juice or raw), allowing them to answer several alternatives. Their preference for leaf size (small, medium, or big) was also asked.

Regarding the acceptance test, 62,65 and 60 tasters participated, respectively, for the harvests: $1^{\text {st }}=60$, $2^{\text {nd }}=90$ and $3^{\text {rd }}=120$ days. The tasters were consumers of vegetables and answered about how much they liked or disliked the curly kales in terms of color, aroma, flavor, texture and global acceptance, using a structured seven-point hedonic scale ( $1=$ disliked very much and $7=$ liked very much) (Meilgaard et al., 2007). More than $65 \%$ of the participants were women, $82 \%$ students, $10 \%$ teachers and the others, university staff, aging between 18 and 30 years. 


\subsection{Statistical analysis}

For the variable chlorophyll, ANOVA was individually applied for each harvest (at 60, 90 and 120 days), considering a completely randomized design. Whenever necessary, the Tukey's test for comparison of means was employed.

For the analysis of the acceptance test data, the univariate analysis of variance of a randomized block design was applied, with 62, 65 and 60 tasters (harvests at 60,90 and 120 days, respectively). Whenever necessary, the Tukey's Test of Multiple Comparisons of Means was employed. For the attributes of the acceptance test, the association among the attributes evaluated was also quantified, calculating the Pearson's correlation coefficient among them. A principal component analysis (PCA) was applied and using this technique, 95\% confidence ellipse for each treatment at each harvest was obtained. The analyses were performed with the help of the software R version 4.0.2 (R Core Team, 2020), considering a level of significance of 5\%.

The interpretation of the data obtained in the ranking test was performed according to the Friedman's test $(p \leq 0.05)$ (Newell \& MacFarlane, 1987).

\section{Results and discussion}

The mean content of the total chlorophyll index in the kale leaves was lower for the kale cultivated using the hydroponic system (Table 1). According to Chitarra \& Chitarra (2005), the duration and intensity of light modify the coloration of the plants, as occurred in this study. The cultivation in hydroponics was performed under red screen (35\%) in protected environment, affecting coloration and intensity of chlorophyll in the leaves.

Candian et al. (2018) verified the value of 48.96 TCI for different collard-green materials under organic and conventional management and they did not observe significant interaction of the systems.

In studies with lettuce, Santos et al. (2001) described that the high total chlorophyll content is an important quality variable for lettuce, since the intense green color provided by chlorophyll makes it attractive for the consumers.

Table 1. Results of the means of the total chlorophyll index (TCI), with standard deviation, of the curly kales using different management systems.

\begin{tabular}{ccccc}
\hline \multirow{2}{*}{ Harvest (days) } & \multicolumn{4}{c}{ Treatment } \\
\cline { 2 - 5 } & $\mathbf{A}=$ Control & $\mathbf{C}=$ conventional* & E=conventional* & F=hydroponics \\
\hline 60 & $51.76(2.37) \mathrm{a}$ & $55.31(1.01) \mathrm{a}$ & $52.96(4.97) \mathrm{b}$ & $\mathrm{NP}$ \\
\hline 90 & $53.75(8.35) \mathrm{a}$ & $52.06(8.56) \mathrm{a}$ & $56.97(5.97) \mathrm{b}$ & $45.00(1.05) \mathrm{b}$ \\
\hline 120 & $61.08(1.68) \mathrm{a}$ & $58.79(6.43) \mathrm{a}$ & $57.28(5.79) \mathrm{ab}$ & $45.81(2.58) \mathrm{b}$ \\
\hline
\end{tabular}

Values followed by different letters, on the same line, differ statistically by the Tukey's test $(p \leq 0.05)$. ${ }^{\text {with }}$ organic fertilizers. NP=Nor Performed.

\subsection{Sensory analysis}

Regarding the color of the kales, the tasters did not identify a significant difference for harvest 1 (at 60 days) between the control kale and the cultivated with organic fertilizers. For harvest 2 (90 days), the kale produced using the hydroponic system presented a lighter green coloration and was similar to kale $\mathrm{C}$ (with organic fertilizer). Nevertheless, treatments A, C and E did not present difference from each other regarding green coloration, being darker. On the other hand, at 120 days (harvest 3), only the hydroponic kale $(\mathrm{F})$ was considered different from all treatments regarding the green color, being lighter (Table 2). In the commercialization of leafy vegetables, appearance aspects such as size, shape, brightness and color of the leaf, mainly, are among the main quality attributes observed by the consumer. Leaf color is of fundamental importance, since the consumer makes the decision of buying (Novo et al., 2010).

For the other attributes of difference (kale aroma, sweet taste, bitter taste, crunchiness), there was no significant difference among the treatments (Table 2) in any of the harvests performed. 
Table 2. Results of the sum of the ranking test of difference and preference of the curly kales produced using the conventional and hydroponic systems.

\begin{tabular}{|c|c|c|c|c|c|}
\hline \multirow{2}{*}{ Attributes evaluated } & \multirow{2}{*}{ Harvest days } & \multicolumn{4}{|c|}{ Treatment } \\
\hline & & $\mathbf{A}$ & $\mathrm{C}$ & $\mathbf{E}$ & $\mathbf{F}$ \\
\hline \multirow{3}{*}{ Color } & 60 & $46 \mathrm{a}$ & $48 \mathrm{a}$ & $46 \mathrm{a}$ & $\mathrm{NP}$ \\
\hline & 90 & $62 \mathrm{a}$ & $51 \mathrm{ab}$ & $64 \mathrm{a}$ & $34 \mathrm{~b}$ \\
\hline & 120 & $60 \mathrm{a}$ & $62 \mathrm{a}$ & $64 \mathrm{a}$ & $25 \mathrm{~b}$ \\
\hline \multirow{3}{*}{ Aroma } & 60 & $41 \mathrm{a}$ & $45 \mathrm{a}$ & $44 \mathrm{a}$ & $\mathrm{NP}$ \\
\hline & 90 & $51 \mathrm{a}$ & $46 \mathrm{a}$ & $53 \mathrm{a}$ & $50 \mathrm{a}$ \\
\hline & 120 & $58 \mathrm{a}$ & $55 \mathrm{a}$ & $48 \mathrm{a}$ & $57 \mathrm{a}$ \\
\hline \multirow{3}{*}{ Sweet taste } & 60 & $39 \mathrm{a}$ & $44 \mathrm{a}$ & $40 \mathrm{a}$ & $\mathrm{NP}$ \\
\hline & 90 & $44 \mathrm{a}$ & $56 \mathrm{a}$ & $56 \mathrm{a}$ & $53 \mathrm{a}$ \\
\hline & 120 & $53 \mathrm{a}$ & $48 \mathrm{a}$ & $49 \mathrm{a}$ & $55 \mathrm{a}$ \\
\hline \multirow{3}{*}{ Bitter taste } & 60 & $52 \mathrm{a}$ & $46 \mathrm{a}$ & $45 \mathrm{a}$ & $\mathrm{NP}$ \\
\hline & 90 & $51 \mathrm{a}$ & $53 \mathrm{a}$ & $56 \mathrm{a}$ & $50 \mathrm{a}$ \\
\hline & 120 & $54 \mathrm{a}$ & $57 \mathrm{a}$ & $55 \mathrm{a}$ & $45 \mathrm{a}$ \\
\hline \multirow{3}{*}{ Crunchiness } & 60 & $47 \mathrm{a}$ & $46 \mathrm{a}$ & $42 \mathrm{a}$ & $\mathrm{NP}$ \\
\hline & 90 & $53 \mathrm{a}$ & $51 \mathrm{a}$ & $60 \mathrm{a}$ & $47 \mathrm{a}$ \\
\hline & 120 & $62 \mathrm{a}$ & $58 \mathrm{a}$ & $49 \mathrm{a}$ & $45 \mathrm{a}$ \\
\hline
\end{tabular}

Values followed by different letters, on the same line, differ statistically by the Friedman's test $(p \leq 0.05)$. $\mathrm{A}=\mathrm{Control} ; \mathrm{C}, \mathrm{E}=$ conventional system (organic fertilizers), $\mathrm{F}=$ Hydroponic. $\mathrm{NP}=$ Not Performed. Harvest 1. Critical value: 16 (three samples and 21 tasters). Harvests 2, 3. Critical value: 22 (four samples and 21 tasters).

Regarding the questions answered before the acceptance test, the most frequent way of curly kale consumption was braised (77\%), followed by salad (55\%), juice (22\%), soup (6\%) and others $(3 \%)$. The frequency of curly kale consumption was: three or more times in the week $26.2 \%$; one or two times in the week $30.8 \%$; twice per month $21 \%$ and once per month $21 \%$. Regarding kale leaf size, $67 \%$ of the tasters prefer kales with medium-sized leaves, 20\% prefer big leaves and the others, small leaves.

The results of the acceptance test of the kale demonstrated that there was no significant difference among the treatments applied for the attributes flavor and texture (Table 3) in any of the harvests.

Table 3. Results of the means and standard deviation (in parenthesis) of the treatments, considering each attribute of the acceptance test (color, aroma, flavor, texture, and global acceptance) of the curly kales.

\begin{tabular}{|c|c|c|c|c|c|}
\hline \multirow{2}{*}{ Attributes } & \multirow{2}{*}{ Harvest days } & \multicolumn{4}{|c|}{ Treatment } \\
\hline & & $\mathbf{A}$ & C & $\mathbf{E}$ & $\mathbf{F}$ \\
\hline \multirow{3}{*}{ Color } & 60 & $5.5(1.44) \mathrm{a}$ & $5.6(1.12) \mathrm{a}$ & $5.6(0.93) \mathrm{a}$ & NP \\
\hline & 90 & $5.5(1.36) \mathrm{a}$ & $5.5(1.29) \mathrm{a}$ & $5.5(1.29) \mathrm{a}$ & $4.7(1.36) \mathrm{b}$ \\
\hline & 120 & $5.1(1.11) \mathrm{b}$ & $5.4(1.16) \mathrm{a}$ & $5.1(1.20) \mathrm{b}$ & $5.1(1.27) \mathrm{b}$ \\
\hline \multirow{3}{*}{ Aroma } & 60 & $5.0(1.32) \mathrm{a}$ & $4.7(1.51) \mathrm{a}$ & $4.7(1.29) \mathrm{a}$ & $\mathrm{NP}$ \\
\hline & 90 & $5.0(1.41) \mathrm{a}$ & $4.6(1.26) \mathrm{ab}$ & $4.6(1.21) \mathrm{b}$ & $4.1(1.38) \mathrm{b}$ \\
\hline & 120 & $4.6(1.19) \mathrm{a}$ & $4.7(1.15) \mathrm{a}$ & $4.7(1.17) \mathrm{a}$ & $4.8(1.35) \mathrm{a}$ \\
\hline \multirow{3}{*}{ Flavor } & 60 & $5.1(1.38) \mathrm{a}$ & $5.2(1.39) \mathrm{a}$ & $5.1(1.25) \mathrm{a}$ & $\mathrm{NP}$ \\
\hline & 90 & $4.7(1.63) \mathrm{a}$ & $4.4(1.58) \mathrm{a}$ & $4.7(1.61) \mathrm{a}$ & $4.4(1.59) \mathrm{a}$ \\
\hline & 120 & $4.4(1.65) \mathrm{a}$ & $4.4(1.52) \mathrm{a}$ & $4.4(1.64) \mathrm{a}$ & $4.7(1.63) \mathrm{a}$ \\
\hline \multirow{3}{*}{ Texture } & 60 & $5.5(1.22) \mathrm{a}$ & $5.4(1.37) \mathrm{a}$ & $5.4(1.32) \mathrm{a}$ & $\mathrm{NP}$ \\
\hline & 90 & $5.2(1.34) \mathrm{a}$ & $5.1(1.47) \mathrm{a}$ & $5.1(1.18) \mathrm{a}$ & $4.8(1.33) \mathrm{a}$ \\
\hline & 120 & $5.3(1.02) \mathrm{a}$ & $5.4(0.88) \mathrm{a}$ & $5.2(0.93) \mathrm{a}$ & $5.1(1.14) \mathrm{a}$ \\
\hline \multirow{3}{*}{ Global acceptance } & 60 & $5.5(1.35) \mathrm{a}$ & $5.4(1.37) \mathrm{a}$ & $5.3(1.22) \mathrm{a}$ & $\mathrm{NP}$ \\
\hline & 90 & $5.1(1.18) \mathrm{ab}$ & $5.2(1.15) \mathrm{a}$ & $4.9(1.22) \mathrm{ab}$ & $4.7(1.16) \mathrm{b}$ \\
\hline & 120 & $5.3(1.09) \mathrm{a}$ & $5.4(1.08) \mathrm{a}$ & $5.2(1.02) \mathrm{a}$ & $5.2(1.21) \mathrm{a}$ \\
\hline
\end{tabular}

Values followed by different letters, on the same line, differ statistically by the Tukey's test $(p \leq 0.05)$. A $=$ Control; $\mathrm{C}, \mathrm{E}=$ conventional system (with organic fertilizers), $\mathrm{F}=$ Hydroponic. $\mathrm{NP}=$ Not Performed.

The treatments did not present significant difference for color in harvest 1 (60 days) (Table 3); nevertheless, a difference in the acceptance of the color was verified among the treatments in the other harvests, in other words, at 90 and 120 days. Treatment $\mathrm{F}$ (hydroponic) received the lowest score when 
compared to the conventional system at 90 days, presenting the lightest green color in the ranking test of difference (Table 2). At 120 days, only treatment $\mathrm{C}$ received a superior mean score for the attribute color compared to the others, which did not differ from each other.

Regarding the acceptance of aroma (Table 3 ), at the $2^{\text {nd }}$ harvest (90 days), there was statistical difference among the samples, with treatment $\mathrm{A}$ being similar to $\mathrm{C}$ and different from the others.

For the harvests at 60 and 120 days using the conventional system, and hydroponics (30 days), the global acceptance of the curly kales did not present differences among the treatments, all being well accepted. For the harvest at 90 days, treatments $C, A$ and E presented the highest global acceptance and did not differ from each other for this attribute; nonetheless, treatment A presented the same global acceptance as treatments $\mathrm{E}$ and $\mathrm{F}$.

The global acceptance and texture of the kales at 90 days remained constant, the other attributes (color, aroma, and flavor) being the most relevant.

All correlations among the variables were significant (Table 4), in other words, all attributes are correlated to each other, with emphasis to the attributes of global acceptance and texture (0.6341), global acceptance with flavor (0.5349), indicating that the main attributes that received the highest scores for curly kale global acceptance were their texture and flavor.

Table 4. Results of the standard deviation of each attribute (diagonal), correlation coefficient (upper triangular part) and respective p-value of the Pearson's linear correlation test (in parenthesis).

\begin{tabular}{cccccc}
\hline \multirow{2}{*}{ Parameters } & Color & Aroma & Flavor & Texture & Global acceptance \\
\cline { 2 - 6 } & 1.2686 & $0.253(p<0.05)$ & $0.272(p<0.05)$ & $0.309(p<0.05)$ & $0.411(p<0.05)$ \\
\hline Color & - & 1.3463 & $0.353(p<0.05)$ & $0.372(p<0.05)$ & $0.476(p<0.05)$ \\
\hline Aroma & - & - & 1.594 & $0.431(p<0.05)$ & $0.535(p<0.05)$ \\
\hline Flavor & - & - & - & 1.280 & $0.634(p<0.05)$ \\
\hline Texture & - & - & - & - & 1.287 \\
\hline Global acceptance & - & & &
\end{tabular}

Considering all variables of the sensory test of acceptance (color, aroma, flavor, texture and global acceptance), with a level of confidence of $95 \%$, it was verified that the same treatment was different in each harvest; nevertheless, the treatments do not differ from each other at 60 and 120 days, with the exception of the harvest at 90 days, in which the kales cultivated using the conventional system (organic fertilizers $\mathrm{C}$ and $\mathrm{E}$ ) do not differ from the Control (A); additionally, the curly kale cultivated in hydroponics (F) is only similar to the kale cultivated under the conventional system using the organic fertilizer E (Figure 1).

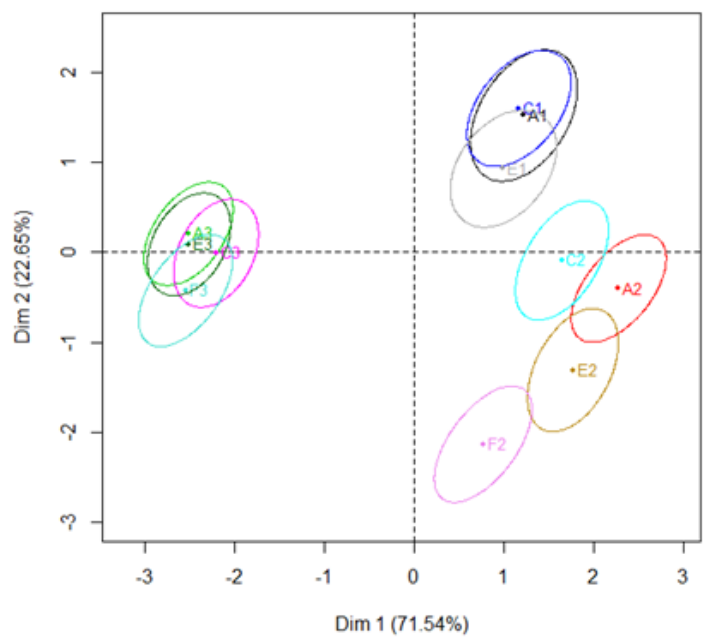

Figure 1. Ellipse of confidence for the centroid of each treatment (A, C, E, F) in each harvest $(1=60$ days, $2=90$ days, and $3=120$ days) considering all attributes evaluated in the sensory test of acceptance (color, aroma, flavor, texture and global acceptance). 


\section{Conclusions}

The kales produced under the conventional production systems using organic fertilizers and hydroponics obtained differences in the chlorophyll content, with the lowest values for the hydroponic kale, which was confirmed in the sensory test as the treatment that led to the lighter green color. In general, the differences did not alter acceptance much since the tasters always used the same part of the hedonic scale among the treatments and harvest periods.

\section{Acknowledgements}

The present work was performed with the financial support of the Brazilian Association of the Industries on Plant Nutrition Technology (ABISOLO), Proex/UFSCar Process $\mathrm{n}^{\circ}$ 23112.003910/2018-10 and Coordination for the Improvement of Higher Education Personnel - Brazil (CAPES) - Financing Code 001.

\section{References}

Associação Brasileira do Comércio de Sementes e Mudas - ABCSEM. (2016). Folhas: Seminário Nacional. Campinas: ABCSEM. Retrieved in 2020, May 6, from https://www.abcsem.com.br/upload/arquivos/O_mercado_de_folhosas_Numeros_e_Tendencias_-_Steven.pdf

Associação Nacional para Difusão de Adubos - ANDA. (2016). Anuário Estatístico. São Paulo: ANDA. Setor de Fertilizantes.

Aular, J., \& Natale, W. (2013). Nutrição mineral e qualidade do fruto de algumas frutíferas tropicais: goiabeira, mangueira, bananeira e mamoeiro. Revista Brasileira de Fruticultura, 35(4), 1214-1231. http://dx.doi.org/10.1590/S010029452013000400033

Bernardi, A. C. C., Verruma-Bernardi, M. R., Werneck, C. G., Haim, P. G., \& Monte, M. B. M. (2005). Produção, aparência e teores de nitrogênio, fósforo e potássio em alface cultivada em substrato com zeólita. Horticultura Brasileira, 23(4), 920-924. http://dx.doi.org/10.1590/S0102-05362005000400011

Brasil. Ministério da Agricultura, Pecuária e Abastecimento. (2020, julho 15). Estabelece as regras sobre definições, exigências, especificações, garantias, tolerâncias, registro, embalagem e rotulagem dos fertilizantes orgânicos e dos biofertilizantes, destinados à agricultura (Instrução Normativa $n^{\circ} 61$, de 8 de Julho de 2020). Diário Oficial [da] República Federativa do Brasil, Brasília, n. 134, Seção 1. Retrieved in 2020, September 1, from https://www.in.gov.br/en/web/dou/-/instrucao-normativa-n-61de-8-de-julho-de-2020-266802148

Candian, J. S., Pelvine, R. A., Martins, B. N. M., Cardoso, A. I. I., \& Oliveira, E. A. (2018). Índice de clorofila de diferentes materiais de couve-manteiga sob manejo orgânico e convencional. In Anais do $55^{\circ}$ Congresso Brasileiro de Olericultura (pp. 493). São Paulo: ABH.

Chitarra, M. I. F., \& Chitarra, A. B. (2005). Pós colheita de frutos e hortaliças: fisiologia e manuseio (2. ed., 785 p.). Lavras: UFLA.

Finatto, J., Altmayer, T., Martini, M. C., Rodrigues, M., Basso, V., \& Hoehne, L. (2013). A importância da utilização da adubação orgânica na agricultura. Revista Destaques Acadêmicos, 5(4), 85-93. Retrieved in 2020, September 1, from https://pdfs.semanticscholar.org/a149/6787b0a29f09036a8614bce0be4d210e5fb3.pdf

Furlani, P. R., Silveira, L. C. O., Bolonhezi, D., \& Faquin, V. (1999). Cultivo hidropônico de plantas. Campinas: IAC.

International Organization for Standardization - ISO. (2006). ISO 8587: Sensory analysis - metodology - ranking. Switzerland: ISO.

Lima, T. J. L., Gazaffi, R., Ceccherini, G. J., Marchi, L., Martinez, M., Ferreira, C. G., \& Sala, F. C. (2018). Volume of cells on trays influences hydroponic lettuce production. Horticultura Brasileira, 36(3), 408-413. http://dx.doi.org/10.1590/s0102053620180320

Meilgaard, M. C., Civille, G. V., \& Carr, B. T. (2007). Sensory evaluation techniques (4th ed.). Boca Raton: CRC Press.

Newell, G. J., \& MacFarlane, J. D. (1987). Expanded tables for multiple comparison procedures in the analysis of ranked data. Journal of Food Science, 52(6), 1721-1725. http://dx.doi.org/10.1111/j.1365-2621.1987.tb05913.x

Noboa, C. S., Ravagnani, C. A., Santos, C. P., Oliveira, B. C., Fernandes, N., Verruma-Bernardi, M. R., \& Sala, F. C. (2019). Produção hidropônica e análise sensorial de couve-de-folhas na forma de maço de plantas jovens. Revista Cincia, Tecnologia \& Ambiente, 9(1), e09121. http://dx.doi.org/10.4322/2359-6643.09121

Novo, M. C. S. S., Prela-Pantano, A., Deuber, R., Torres, R. B., Trani, P. E., \& Bron, I. U. (2010). Caracterização morfológica e da coloração de folhas de couve do banco de germoplasma do Instituto Agronômico de Campinas. Retrieved in 2020, September 1, from http://www.infobibos.com/Artigos/2011_1/couve/index.htm

Oliveira, L. B., Accioly, A. M. A., Santos, C. L. R., Flores, R. A., \& Barbosa, F. S. (2014). Características químicas do solo e produção de biomassa de alface adubada com compostos orgânicos. Revista Brasileira de Engenharia Agrícola e Ambiental, 18(2), 157-164. http://dx.doi.org/10.1590/S1415-43662014000200005

Olsen, H., Aaby, K., \& Borge, G. I. (2009). Characterization and quantification of flavonoids and hydroxycinnamic acids in curly kale (Brassica oleracea L. convar. acephala Var. sabellica) by HPLCDAD-ESI-MSn. Journal of Agricultural and Food Chemistry, 57(7), 2816-2825. PMid:19253943. http://dx.doi.org/10.1021/jf803693t 
R Core Team. (2020). R: A language and environment for statistical computing. Vienna, Austria: R Foundation for Statistical Computing. Retrieved in 2020, September 1, from https://www.R-project.org/

Santos, R. H. S., Silva, F., Casali, V. W. D., \& Condé, A. R. (2001). Conservação pós-colheita de alface cultivada com composto orgânico. Pesquisa Agropecuária Brasileira, 36(3), 521-525. http://dx.doi.org/10.1590/S0100-204X2001000300017

Vilela, N. J., \& Macedo, M. M. C. (2000). Fluxo de poder no agronegócio: o caso das hortaliças. Horticultura Brasileira, $18,88-94$.

Trani, P.E., Tivelli, S.W., Blat, S.F., Prela-Pantano, A., Teixeira, E.P., Araújo, H.S, Feltran, J.C., Passos, F.A., Figueiredo, J.B. \& Novo, M.C.S.S. (2015). Couve de folha: Do plantio a pós-colheita (Série Tecnologia APTA. Boletim Técnico IAC 214).

Campinas: Instituto Agronômico.

Funding: The present work was performed with the financial support of the Brazilian Association of the Industries on Plant

Nutrition Technology (ABISOLO), Proex/UFSCar Process no 23112.003910/2018-10 and Coordination for the Improvement of Higher Education Personnel - Brazil (CAPES) - Financing Code 001. 